\title{
Introduction to Doreen Massey's 2014 Tokyo Lecture
}

\section{MORI Masato}

Faculty of Humanities, Law and Economics, Mie University; 1577 Kurimamachiya-cho, Tsu City, Mie, Japan.

E-mail: masamori@human.mie-u.ac.jp

Doreen Massey, Emeritus Professor of Geography at the Open University, visited Japan in March 2014. The following paper- "Geography and Politics"-summarises Professor Massey's lecture at the Association of Japanese Geographers 2014 Spring Meeting on March 27th at Kokushikan University. Prior to this lecture, Professor Massey gave a keynote speech titled-"Repositioning Place in a Global Age"-in Osaka on March 21st and also acted as discussant for two workshops: "Historical Conditions and Current Forms of Gentrification in Osaka" held at Osaka City University on March 24th and "Globalisation, Gender, Space and Place" held at Ochanomizu University on March 26th. Professor Massey returned home from Narita International Airport on March 30th.

Professor Massey's visit to Japan was first officially discussed following her annual event to commemorate her academic achievement at the Open University- "Spatial Politics: A Conversation"-held in London on March 8th, 2013. The itinerary for Professor Massey's visit was then discussed and decided in a series of email exchanges after October 2013. Funding for her trip to Japan was granted by two research projects: "Locally Sensitive Gender Geographies and the Construction of Global Networks" (principal investigator: Keichi Kumagai) and "Towards the Creation of Inclusive Cities and the Formulation of a Geography of Support based on Support for a Broadly Defined 'Homeless' Population in East Asia' (principal investigator: Toshio Mizuuchi).

Following her series of lectures in Japan, Professor Massey received the Presidential Achievement Award at the Annual Meeting of the Association of American Geographers in Tampa. The fact that Professor Massey has been awarded such honours even outside the UK-such as medals, awards and honorary doctorates after the mid1990s-is illustrative of the impact of her work in Europe and North America. In addition to her academic achievements, it should be noted that Professor Massey has also been actively involved in political movements in Latin America and South Africa.

In 1973, Professor Massey published a paper titled
"Towards a Critique of Industrial Location Theory" criticising old-fashioned location theory, in favour of Marxism geography. Her academic endeavour reached to the publication of Spatial Divisions of Labour (Massey 1984a). Drawing on the Althusserian concept of 'over determination, the book asserts the importance of super-structural elements such as gender and race as well as the material base in determining industrial location. In her elaboration, unevenness and place difference, in short locality, always evolve from a complex process of capitalism situated in specific time and space. Her discussion of a global sense of place rejects simplified notions of place as essential, coherent and static. Instead she insists that places have multiple identities, are always changing, and are folded inside and outside. Geography matters because '[S]patial distributions and geographical differentiation may be the result of social processes, but they also affect how those processes work' (Massey 1984b: 4).

Her concern to philosophically examine space, place and time resulted in For Space (Japanese translation 2014). The book elaborates geographical ideas such as 'power geometry', 'throwntogetherness' and 'politics of place beyond place' to address 'spatialized social practices and relations, and social power', or the geography of politics and power 'as refracted through and often actively manipulating space and place' (Massey 2005: 166). The fact that Key Texts in Human Geography (Hubbard et al. 2008), a work which introduces 25 of the most influential books in human geography, includes Massey's For Space and Spatial Divisions of Labour among its key texts is indicative of the high esteem accorded to her work in Anglophone geography.

Professor Massey's lectures in Japan were based on discussions in For Space. In her Osaka lecture, Professor Massey reiterated that places are always created as global social relationships: place as event. She further explored how negotiations of place are unequal, and how politics, economics and cultures of space are actively used in the production of that inequality by introducing stories about political movements for the protection of locals and 
places. To understand the unequal relationship between us and distanced others-relatedness-entails care and responsibility for others. This is a relational politics of space, and the following article-"Geography and Politics"-provides the reader with an opportunity to consider this relational understanding of geographical politics.

\section{References}

Hubbard, P., Kitchin, R. and Valentine, G. eds. 2008. Key texts in human geography. Los Angeles: Sage.

Massey, D. B. 1984a. Spatial divisions of labour: Social structures and the geography of production. London: Macmillan.

Massey, D. B. 1984b. Introduction: Geography matters. In Geography Matters!: A reader, ed. D. Massey and J. Allen, 1-11. Cambridge: Cambridge University Press.

Massey, D. B. 2005. For space. London: Sage. 